\title{
PELUANG, TANTANGAN, DAN STRATEGI ZAKAT DALAM PEMBERDAYAAN EKONOMI UMAT
}

\author{
Siti Zumrotun \\ Fakultas Syariah IAIN Salatiga \\ Jalan Nakula Sadewa No. 4-5, Kembangarum, Salatiga \\ E-mail: sitizumrotun67@gmail.com
}

\begin{abstract}
Opportunities, Challenges, and Strategy of Zakat in People's Economic Empowerment of People. Basically, zakat in Islamic teaching is the one of effective and strategic ways to be developed in increasing prosperous of people. So, it can be very potential. The potency of zakat will be great and useful if the institution of zakat administrator can manage effectively and overcome all classic problems always faced by administrators. Managerial skill, accountability, integrity, and truth are the main capitals to manage zakat. Meanwhile, empowering, supervising, and teaching on the people who received zakat (mustahiq) are some important things that should be thought. Therefore, the institution of zakat management should get the way to change people perspective from receiver to giver (mustahiq to muzakki). The strategies are to accustom for paying zakat, to be creative and smart in collecting zakat, distribute zakat effectively, create high quality of human resources, and to be focus on the programs of developing zakat.
\end{abstract}

Keywords: opportunities, challenges, strategy, zakat, people's economic

\begin{abstract}
Peluang, Tantangan, dan Stategi Zakat dalam Pemberdayaan Ekonomi Umat. Basically, zakat in Islamic teaching is the one of effective and strategic ways to be developed in increasing prosperous of people. So, it can be very potential. The potency of zakat will be great and useful, if the institution of zakat administrator can manage effectively and overcome all classic problems always faced by administrators. Managerial skill, accountability, integrity, and truth are the main capital to manage zakat. Meanwhile, empowering, supervising, and teaching on the people who received zakat (mustabiq) is one of the important things that should be thought. Therefore, the institution of zakat management should get the way how to change people perspective from receiver to giver (mustabiq to muzakki). The strategies are to accustom for paying zakat, to be creative and smart in collecting zakat, distribute zakat effectively, create high quality of human resources, and to be focus on the programs of developing zakat
\end{abstract}

Kata kunci: peluang, tantangan, strategi, zakat, ekonomi umat

\section{Pendahuluan}

Zaman modern banyak menimbulkan ketimpanganketimpangan dan ketidakmerataan, terutama dalam masalah sosial ekonomi. Banyak orang kaya yang semakin kaya, sementara orang miskin tetap dalam kemiskinannya. Kondisi ini dikritik oleh Alquran sejak zaman pertumbuhan dan perkembangan Islam. Alquran mengutuk orang-orang yang menumpuk harta sebagaimana tertera dalam surah al-Takâtsur ayat 1 , yang artinya, "Bermegah-megahan telah melalaikan kamu".

Dalam rangka menekankan rasa solidaritas dan juga menekan ketamakan orang-orang kaya, Islam sebagai

Naskah diterima: 13 Agustus 2015, direvisi: 4 September 2015, disetujui untuk terbit: 10 November 2015. agama samawi menaruh perhatian penuh terhadap nasib orang-orang miskin. Tidak sekadar berupa imbauan kepada para umatnya untuk memperhatikan orangorang miskin, akan tetapi mewajibkan zakat menjadi rukun Islam sesudah sahadat dan salat. Zakat sebagai rukun Islam yang ketiga harus dilaksanakan oleh umat Islam sebagaimana kewajiban salat ${ }^{1}$, dengan penuh ke-

\footnotetext{
1 Alquran selalu menggandengkan zakat dengan kewajiban salat. Hal itu ditegaskan dalam 82 ayat. Ini menunjukkan bahwa keduanya memiliki keterkaitan yang sangat erat. Wahbah Zuhayly, Zakat Kajian Pelbagai Madzhab, diterjemahkan oleh Agus Efendi, (Bandung: Remaja Rosda Karya, 1995), h. 89. Hal ini juga membuktikan bahwa syariat Islam dituangkan dalam bentuk yang sangat sistematis. Ayat yang tampaknya individual selalu diiringi dengan ayat-ayat yang bernuansa sosial. Bahkan syariat Islam tidak ia membenarkan seseorang melupakan dan mengabaikan kehidupan dunia, selain harus berinteraksi dengan Allah. Abdul Wahab Khallaf, Sejarah Pembentukan dan Perkembangan Hukum Islam, penyadur
} 
sadaran tinggi serta penuh tanggungjawab. Demikian zakat ini akan menjadi sumber dana yang potensial dalam menunjang pembangunan nasional terutama di bidang agama dan ekonomi. Hal ini tentunya akan membantu peningkatan pendapatan dan kesejahteraan umat.

Zakat merupakan ibadah sosial (horisontal kemanusiaan), sementara salat merupakan ibadah individual (vertikal ketuhanan). Imam Ghazali dalam kitab

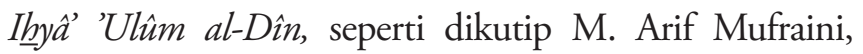
mengatakan bahwa zakat merupakan alat uji derajat keimanan seorang hamba yang mencintai Allah, melalui upaya meminimalisisasi konsumsi atas dasar kecintaan kepada Allah Swt. ${ }^{2}$ Salah satu upaya yang efektif dalam memahami hikmah zakat dalam Islam yaitu dengan memahami ayat-ayat zakat melalui jalan praksis agar mampu memberikan solusi-solusi riil yang terbaik atas segala problem masyarakat khususnya terkait dengan masalah keterbelakangan ekonomi. ${ }^{3}$

Bangsa Indonesia merupakan bangsa yang mayoritas penduduknya beragama Islam. Namun, jika ditinjau dari sisi ekonomi masih banyak umat Islam yang hidup di bawah layak. Fenomena ini memunculkan pertanyaan, apakah yang menyebabkan umat Islam terbelakang dalam bidang ekonomi? Siapakah yang bersalah. Orang miskin yang malas bekerja, tidak punya skill, tidak berpendidikan? Atau orang kaya yang tidak mau peduli terhadap nasib ekonomi mereka.

Terlepas dari siapa yang salah dalam menjawab pertanyaan tersebut, sebenarnya hakikat kewajiban zakat dalam Islam merupakan cara paling efektif dan strategis yang layak untuk dikembangkan menjadi instrumen penting dalam meningkatkan kesejahteraan orang-orang miskin. Zakat yang berasal orang-orang kaya bukan berarti melecehkan hasil keringat mereka, namun dengan zakat justru akan menambah harta mereka dan tidak berkurang sedikipun. Pernyataan ini sejalan dengan makna zakat baik secara etimologi maupun secara terminologi fikih. Secara etimologi, zakat berarti suci, berkembang, berkah, tumbuh, bersih dan baik. ${ }^{4} \mathrm{Hal}$ itu dimaknai demikian karena

\footnotetext{
Wajidi Sayadi, (Jakarta: Raja Grafindo Persada, 2001), h. 4.

${ }^{2}$ M. Arif Mufraini, Akuntasi dan Manajemen Zakat, (Jakarta: Media Group,2006), h. 5.

${ }^{3}$ Nafis Irkhami, Islamic Work Ethics Membangun Etos Kerja Islami,(Salatiga: STAIN Salatiga Press, 2014), h. 10.

${ }^{4}$ Abdul Aziz Dahlan, dkk., "Zakat"Ensiklopedi Hukum Islam, (Jakarta: PT Ichtiar Baru Van Hoeve 1996), h. 1985.
}

merupakan upaya mensucikan diri dari kotoran kikir dan dosa serta menyuburkan pahala melalui pengeluaran sedikit dari nillai harta pribadi untuk umat yang miskin. Hal ini sejalan dengan Surah al-A'lâ: 14 yang artinya, "Sungguh beruntunglah orang-orang yang mensucikan diri". Sedangkan secara terminologi zakat dimaknai dengan penyerahan atau penunaian hak yang wajib yang terdapat di dalam harta untuk diberikan kepada orang-orang yang berhak. ${ }^{5}$ Ketentuan yang sudah pasti dari Allah Swt. ini memiliki implikasi strategis dalam membangun kesejateraan umat. Setiap orang yang membayar zakat, mereka langsung bisa menunaikan dua aspek kewajiban yairu aspek agama dan aspek ekonomi. ${ }^{6}$

Definisi tersebut mengandung makna bahwa zakat dianggap sebagai pemindahan hak milik kepada yang berhak menerimanya. Dengan demikian, muzaki sudah tidak bisa menarik kembali barang atau harta tersebut dan juga sudah tidak bisa menggunakan harta tersebut dengan cara apapun. Oleh karena itu, Islam dengan aturan fikihnya memberikan beberapa persyaratan tertentu tentang harta yang dikenai wajib zakat.

Pertama, kepemilikan sempurna, (milkiyyah tammah/ genunine ownership), bahwa aset kekayaan tersebut harus berada di bawah kekuasaan seseorang secara sempurna tanpa ada hak orang lain di dalamnya. Secara hukum, pemilik aset kekayaan berhak membelanjakan kekayaan tersebut sesuai dengan keinginannya. Kepemilikan yang tidak cacat hukum ini sangat penting diketahui oleh para muzaki juga para amil zakat.

Kedua, aset produktif atau berpotensi untuk produktif (mengalami perkembangan aset), maksud produktivitas di sini adalah bahwa dalam proses pemutarannya (komersialisasi) mendatangkan hasil atau pendapatan tertentu sehingga tidak terjadi pengurangan nilai atas kapital aset. Oleh karena itu, tidak diwajibkan zakat atas tempat tinggal, kuda tunggangan, baju yang dipakai, buku, peralatan rumah tangga dan lain-lain karena semua itu termasuk dalam kategori kebutuhan primer yang tidak dapat berkembang (konsumtif). Zakat mendorong umat Islam untuk selalu berinvestasi. ${ }^{7}$

\footnotetext{
${ }^{5}$ Suyitno (ed.), Anatomi Figh Zakat, (Yogyakarta: Pustaka Pelajar, 2005), h. 12-14.

${ }^{6}$ Didin Hafidhuddin, Zakat dalam Perekonomian Modern, (Jakarta: Gema Insani, 2002), hlm. 15.

7 Ada Hadis yang menjelaskan tentang hal tersebut, yang artinya, "Barang siapa yang menjadi wali anak yatim hendaknya dia mendagangkan harta anak tersebut agar tidak dimakan oleh zakat". (Muttafaq 'Alayh).
} 
Ketiga, harus mencapai nisab, yaitu syarat wajib minimal aset yang dapat dikategorikan sebagai aset wajib zakat. Islam mensyaratkan dalam pelaksanaan zakat mal agar aset yang dizakati mencapai nisab tertentu. Ini artinya hanya aset surplus yang menjadi objek zakat. Sebab, tidak logis apabila zakat diambil dari orang fakir dan diberikan kepada orang fakir. Selain itu yang perlu diperhatikan ialah nisab ditentukan pada akhir tahun dengan ketentuan harga pasar.

Keempat, aset surplus nonkebutuhan primer (sandang, pangan, dan papan), yaitu aset kepemilikan yang melebihi kebutuhan primer. Cara menetukan kebutuhan primer masing-masing muzaki berbeda-beda sehingga sulit untuk menentukannya. Oleh karena itu, dikembalikan kepada masing-masing muzakki dengan menyesuaikan kebutuhan primer. Sebagai contoh, misalnya seorang muzaki memiliki tiga mobil, maka pertanyaannya berapa mobil yang menjadi kebutuhan primer. Selanjutnya dapat dipertimbangkan hal yang lain, misalnya jumlah anak yang menjadi tanggungjawab muzaki. Muzaki yang hanya memiliki satu anak akan berbeda kebutuhan primernya dengan yang memiliki lima anak. Muzaki yang memiliki mobil merk Ferarri otomatis berbeda aset dengan yang memiliki mobil Avanza. Jika memiliki satu rumah sudah cukup, maka rumah yang lainnya akan menjadi wajib zakat.

Kelima, tidak memiliki tanggungan utang. Aset wajib zakat adalah aset yang sudah dikurangi utang. ${ }^{8}$ Hal ini didasarkan pada asas yang menyatakan bahwa hak orang yang meminjamkan utang harus didahulukan daripada hak golongan penerima zakat. Namun, demikian jika utang itu sudah dibayarkan, aset tersebut menjadi aset yang wajib dibayarkan zakatnya.

Keenam, kepemilikan satu tahun penuh, sebagian aset wajib zakat, seperti binatang ternak, aset keuangan, dan barang dagangan (komoditas) harus dimiliki selama satu tahun penuh menurut perhitungan kalender Hijrah, umumnya dimulai dari bulan Ramadan. Hikmah disyaratkan satu tahun penuh ini adalah untuk mempermudah seseorang atau perusahaan dalam melihat secara jelas perkembangan nilai aset yang dimiliki. Hal ini juga mengandung makna bahwa seorang muzaki hanya diwajibkan membayar zakat sekali dalam satu tahun. ${ }^{9}$

${ }^{8}$ Ada perbedaan pendapat ulama tentang ketentuan zakat harta yang ada dalam utang. Hasby Ash Shidiqy dalam bukunya Pedoman Zakat mengemukakan beberapa perbedaan tersebut berdasarkan hadishadis Rasulullah. Lihat Hasbi Ash Shiddiqy, Pedoman Zakat, (Jakarta: Bulan Bintang, 1984), h.50.

${ }^{9}$ M. Arif Mufraini, Akuntasi dan Manajemen Zakat, h. 19-25.

\section{Fungsi Strategis Lembaga Amil Zakat}

Mengubah orang miskin menjadi kehidupan yang layak atau kehidupan yang serba cukup (mengubah mustahik menjadi muzaki), tidaklah semudah membalikkan tangan. Namun, harus ada pelbagai cara atau strategi yang terencana dengan baik. Selain itu juga dibutuhkan kemampuan serta SDM yang memadai. Dalam menjalankan kewajibannya untuk melakukan usaha mulia seperti di atas, perlunya payung hukum berupa Undang-undang atau peraturan untuk lancarnya kegiatan. Dalam hal ini, pemerintah menaruh perhatian yang serius terhadap pelaksanaan zakat bagi umat Islam. Keseriusan ini bisa dilihat diterbitkannya UU No. 33 Tahun 1999 yang kemudian diperbarui dengan UU No. 23 Tahun $2011 .{ }^{10} \mathrm{UU}$ ini seterusnya menjadi payung hukum masyarakat dalam mengelola zakat bagi umat Islam.

Dalam upaya optimalisasi sistem zakat sebagai salah satu proses redistribusi income, posisi amil dalam kelompok delapan asnâf memiliki peranan yang luar biasa dan cukup unik. Artinya sistem zakat akan banyak mempunyai ketergantungan terhadap profesionalisme dari amil. Secara konsep dapat dipahami bahwa dengan semakin tinggi tingkat keprofesionalan amil semakin tinggi kesejahteraan para mustahik, khususnya amil, mengingat konsep fikih secara jelas mengatur bahwa hak mereka adalah $12.5 \%$ atau $1 / 8$ dari harta terkumpul. ${ }^{11}$

Pengelolaan zakat secara profesional memerlukan tenaga yang terampil, menguasai masalah-masalah yang berhubungan dengan zakat, seperti muzaki, nisab, hawl, juga mustahik zakat itu sendiri. Selain itu, pengelola zakat (amil) juga harus memiliki dedikasi yang tinggi dalam manjalankan tugasnya karena zakat merupakan ibadah sosial yang formal, terikat dengan syarat, dan rukun tertentu. ${ }^{12}$

Selanjutnya amil zakat dalam hal ini adalah Badan Amil Zakat (BAZ) ataupun LAZ bisa dikatakan

10 Undang-undang yang ada dirasakan tidak cukup untuk mengakomodasi perkembangan potensi zakat di Indonesia, untuk itu Komisi VIII DPR RI merumuskan undang-undang tentang pengelolaan zakat yang baru. Namun, UU Zakat baru yang diresmikan 20 Oktober 2011 menggantikan UU No. 38 Tahun 1999 dianggap menimbulkan kontroversi di kalangan praktisi, akademisi, masyarakat, Lembaga Amil Zakat (LAZ), dan pihak yang terkait (stake holder) lainnya. UU yang baru tersebut dikhwatirkan akan dibubarkannya LAZ dan mengerdilkan peran mandiri masyarakat dalam memberdayakan dana zakat. https:// shareeducation.wordpress.com

${ }^{11}$ M. Arif Mufraini, Akuntansi dan Manajemen Zakat, h. 186.

${ }^{12}$ Sahal Mahfud, Nuansa Figh Sosial, (Yogyakarta: LkiS, 2004), h. 147. 
akuntabel jika memiliki beberapa pilar yakni: amanah, profesional, dan transparan. Amanah merupakan kunci utama jaminan kepercayaan masyarakat. Tanpa adanya sifat ini, kehancuran perekonomian akan segera tampak. Sikap amanah akan menunjukkan tingginya moral pengelola zakat sehingga BAZ/LAZ akan bisa berjalan dan teksis di masyarakat. Namun, jika yang terjadi sebaliknya otomatis lembaga zakat itu hilang dengan sendirinya karena masyarakat sudah tidak percaya.

Profesional, efisiensi, dan efektivitas manajemen dituntut dari semua pengurus Badan Amil Zakat. Sistem kontrol yang baik akan terjadi jika jiwa transparansi dalam pengelolaan dana umat dimiliki para pengurus. Kemudahan akses para muzaki untuk mengetahui bagaimana penasarufan hartanya merupakan hal yang sangat urgen. ${ }^{13}$ Selain itu seorang amil juga harus memiliki leadership skill, manajerial skill, inovatif, serta no profit motives. ${ }^{14}$

Secara konsep tugas-tugas amil adalah: pertama melakukan pendataan muzaki dan mustahik, melakukan pembinaan, menagih, mengumpulkan, dan menerima zakat. Selain itu mendoakan muzaki saat menyerahkan zakat, kemudian menyusun penyelenggaraan sistem administrasi dan manajerial dana zakat yang terkumpul. Kedua, memanfaatkan data mengenai peta mustahik dan muzaki, kemudian memetakan jumlah kebutuhannya, dan menentukan kiat pendistribusiannya. Selanjutnya melakukan pembinaan berlanjut untuk mustahik yang menerima dana zakat. ${ }^{15}$ Sedangkan tugas amil menurut fatwa MUI No. 8 Tahun 2011 tentang amil zakat antara lain, pertama, penarikan /pengumpulan zakat yang meliputi pendataan wajib zakat, penentuan objek wajib zakat, besaran nisab zakat, besaran tarif zakat dan syarat-syarat tertentu pada masing-masing objek zakat. Kedua, pemeliharaan zakat yang meliputi inventarisasi harta pemeliharaan, serta pengamanan harta zakat, ketiga, pendistribusian harta, yang meliputi penyaluran harta zakat agar sampai kepada mustahik zakat secara baik dan benar, dan pelaporan.

Hal yang tidak kalah pentingnya dalam memaksimalkan fungsi zakat adalah bagaimana bentuk pembagian zakat tersebut kepada yang berhak yakni kepada delapan asnaf. Sejak dahulu pemanfaatan zakat dapat digolongkan menjadi empat bentuk. Pertama, bersifat konsumtif tradisional, yaitu proses pembagian

\footnotetext{
${ }^{13}$ Suyitno (ed. ), Anatomi Figh Zakat, h. 144-145.

${ }^{14}$ https://nrriantoalarif.wordpress.com

${ }^{15}$ M. Arif Mufraini, Akuntansi dan Manajemen Zakat, h. 188.
}

langsung kepada para mustahik. Kedua, konsumtif kreatif, yaitu proses pengonsumsian dalam bentuk lain dari barangnya semula, seperti diberikan dalam bentuk bea siswa, gerabah, cangkul, dan sebagainya. Ketiga, bersifat produktif tradisional yaitu proses pemberian zakat diberikan dalam bentuk benda atau barang yang diketahui produktif untuk satuan daerah yang mengelola zakat seperti pemberian kambing, sapi, becak, dan sebagainya. Keempat bersifat produktif kreatif, yaitu proses perwujudan pemberian zakat dalam bentuk permodalan bergulir baik untuk proses usaha program sosial, home industri, atau tambahan modal usaha kecil. ${ }^{16}$

Pengenalan dan pemahaman terhadap mustahik zakat juga perlu menjadi perhatian utama dalam memberikan pendistribusian yang lebih efektif dan proporsional. Hal ini bisa dilakukan dengan mengadakan survei awal tentang keberadaan mustahik dan mengklasifikasikannya menurut motivasi dan kesungguhan mereka untuk mengubah dirinya dari mustahik menjadi muzaki. Mereka yang memiliki "kesungguhan" untuk mengubah dirinya dengan cara "sanggup" melakukan kegiatan usaha dipertimbangkan untuk menerima harta zakat yang cukup untuk usaha. Sementara mereka yang "tidak sanggup" melakukan kegiatan usaha tidak perlu diberi bagian zakat yang besar tetapi diberikan dalam bentuk konsumtif.

Mereka yang masih dalam usia sekolah, maka pemberian zakat dapat diwujudkan dalam bentuk bea siswa yang langsung diberikan kepada lembaga pendidikannya agar mereka dapat memperoleh bekal keterampilan dan ilmu yang memadai sehingga dalam mengarungi derasnya tantangan kehidupan global memiliki keunggulan kompetitif. ${ }^{17}$

Dalam upaya pemberdayaan usaha mereka, pengelola baik BAZ ataupun LAZ menyediakan pendampingan manajemen kepada para mustahik tersebut. Ini dimaksudkan agar dalam mengatur dana dari zakat tidak hanya menuruti kemauannya sendiri yang akhirnya tujuan zakat tidak tercapai. Pemberian modal kepada mereka pada hakikatnya adalah memberi makan dalam jangka panjang. Apalagi tingkat kompetisi kehidupan yang makin intens dan berat. Mereka yang memiliki bekal pengetahuan saja yang dapat mengarungi bahtera kehidupan.

\footnotetext{
${ }^{16}$ Suyitno (ed.), Anatomi Figh Zakat, h. 3-4.

${ }^{17}$ Amad Rofiq, Fiqh Kontekstual dari Normatif ke Pembaharuan Sosial, (Yogyakarta: Pustaka Pelajar, 2004), h. 313.
} 
Kaitannya dengan peran zakat untuk mengubah mustahik menjadi muzaki ini Kementerian Agama RI menegaskan dalam keputusannya No. 373 Tahun 2003 tentang "Prosedur pendayagunaan hasil pengumpulan zakat untuk usaha produktif ditetapkan sebagai berikut: (1) melakukan studi kelayakan; (2) menetapkan jenis usaha produktif; (3) melakukan pembimbingan dan penyuluhan; (4) melakukan pemantauan, pengendalian dan pengawasan; (5) mengadakan evaluasi dan (6) membuat pelaporan.

Hal yang terpenting dalam pengelolaan dan pendistribusian perlu dipikirkan kembali adalah efektivitas, profesionalitas, dan akuntabilitas manajemen pengelolaannya. Zakat sebagai aset ekonomi umat dapat dikelola dengan secara lebih baik. Upaya demikian memerlukan keberanian di dalam memperbaiki pemahaman masyarakat. Mereka yang diserahi amanat sebagai amil untuk mensosialisasikan kepada masyarakat, dan mengaplikasikannya. Sistem manajemen pengelolaan yang tardisional sudah saatnya ditinggalkan diganti dengan manajemen pengadministrasian dan pertagungjawaban yang baik, seperti pernah dilakukan pada awal Islam. Jika langkah itu dilakukan, maka kepercayaan muzaki kepada BAZ/LAZ akan lebih besar. Dengan demikian, fungsi zakat sebagai potensi pensejahteraan ekonomi umat tidak hanya menjadi jargon pelatihan dan retorika politik tetapi benar-benar merupakan tugas nyata untuk mensejahterakan, memberdayakan, dan sekaligus membangun sektor riil menjadi bergerak dinamis. Hal itu tentunya akan menjadikan fundamental dan ekonomi masyarakat menjadi kuat. Oleh karena itu, zakat benarbenar mampu mentransformasikan nilai-nilai Islam melalui pendayagunaannya sehingga mengubah siklus kemunduran menjadi siklus kemajuan.

\section{Tantangan Zakat dalam Pemberdayaan Ekonomi Umat}

Tantangan pengelolaan zakat di Indonesia dapat bersumber dari pelbagai segi, bersumberkan dari sikap para muzkaki, mustahik dan juga badan pengelola zakat. Pelbagai hambatan atau tantangan tersebut antara lain ${ }^{18}$, pertama, minimnya sumber daya manusia yang berkualitas. Pekerjaan menjadi seorang pengelola zakat (amil) belumlah menjadi tujuan hidup atau profesi dari seseorang, bahkan dari lulusan ekonomi syariah sekalipun. Para sarjana-meskipun dari lulusan Ekonomi Syariah-lebih memilih untuk berkarir

\footnotetext{
${ }^{18}$ http://alarifs.blogspot.co.id
}

di sektor keuangan seperti perbankan atau asuransi. Sangat sedikit orang yang memilih untuk berkarier menjadi seorang pengelola zakat. Menjadi seorang amil belumlah menjadi pilihan hidup dari para sarjana itu, karena tidak ada daya tarik kariernya. Padahal lembaga amil membutuhkan banyak sumber daya manusia yang berkualitas agar pengelolaan zakat dapat profesional, amanah, akuntabel, dan transparan. Karena sesungguhnya kerja menjadi seorang amil mempunyai dua aspek tidak hanya aspek materi semata namun aspek sosial juga sangat menonjol.

Kedua, pemahaman fikih amil yang belum memadai. Masih minimnya pemahaman fikih zakat para amil menjadi salah satu hambatan dalam pengelolaan zakat. Hal itu disebabkan karena menjadikan fikih hanya dimengerti dari segi tekstual semata bukan konteksnya. Banyak para amil terutama yang masih berpikir tradisional sangat kaku memahami fikih sehingga tujuan utama zakat tidak tercapai. Sebenarnya dalam penerapan zakat di masyarakat yang harus diambil adalah ide dasarnya, yaitu bermanfaat dan berguna bagi masyarakat serta dapat memberikan kemaslahatan bagi umat dan mampu menjadikan mustahik tersebut pribadi yang mandiri dan tidak tergantung oleh pihak lain. Bukan berarti para amil diberikan kesempatan untuk berijtihad dan berkreasi tanpa batas, mereka tetap harus berusaha melakukan terobosan-terobosan baik pengelolaan zakat agar tetap sesuai dengan syariat. Sistem pengawasan yang terdapat di semua institusi keuangan syariah termasuk di dalamnya institusi pengelola zakat, mewajibkan adanya unsur Dewan Pengawas Syariah (DPS) di dalam struktur organisasinya. Dewan itu berfungsi melakukan pengawasan terhadap pengelolaan manajemen agar tidak menyimpang dari aturan syariat.

Ketiga, rendahnya kesadaran masyarakat. Kesadaran membayar zakat masyarakat saat ini masih minim. Sudah melekat dalam benak sebagian kaum muslim, perintah zakat itu hanya diwajibkan pada bulan Ramadan saja. Itupun masih terbatas pada pembayaran zakat fitrah. Zakat bukanlah sekadar ibadah yang diterapkan pada bulan Ramadhan semata, melainkan juga dapat dibayarkan pada bulan lainnya. Ide dasar zakat untuk kemaslahatan umat telah bergeser menjadi sekadar ibadah ritual semata yang dikerjakan dengan ibadah puasa. Terdapatnya syarat haul (satu tahun kepemilikan) menandakan bahwasanya zakat tersebut tidak mengenal pembayaran pada satu bulan tertentu saja, melainkan setiap bulan zakat dapat dibayarkan. 
Apabila kesadaran masyarakat akan pentingnya zakat untuk peningkatan kesejahteraan dan kemakmuran umat sudah semakin baik, tentunya berimbas pada peningkatan penerimaan zakat.

Keempat, rendahnya teknologi yang dipakai. Penerapan teknologi yang ada pada suatu lembaga zakat masih sangat jauh bila dibandingkan dengan diterapkan pada institusi keuangan. Hal itu menjadi salah satu kendala penghambat kemajuan pendayagunaan zakat. Teknologi yang diterapkan pada lembaga amil masih terbatas pada teknologi standar biasa. Sistem akuntansi, administrasi, penghimpunan maupun pendayagunaan haruslah menggunakan teknologi terbaru, agar dapat menjangkau segala kelompok masyarakat terutama segmen kalangan menengah atas yang nota bene-nya memiliki dana berlebih. Teknologi tinggi dibutuhkan agar lembaga zakan memiliki mobilitas tinggg. Lembaga amil zakat yang mampu melakukan inovasi dalam memberikan kemudahan kepada muzaki akan semakin mampu mempertinggi proses penghimpunan dana. Misalkan melakukan kerjasama dengan perbankan untuk pembayaran zakat via ATM atau mobile-banking. Penggunaan teknologi selain memberikan kemudahan kepada muzaki untuk memberikan donasinya juga mempermudah lembaga amil zakat pada penghimpunan dana di masyarakat.

Kelima, sistem informasi zakat. Inilah salah satu hambatan utama yang menyebabkan zakat belum mampu memberikan pengaruh yang signifikan dalam perekonomian. Lembaga amil zakat yang ada belum mampu mempunyai atau menyusun suatu sistem informasi zakat yang terpadu antaramil. Harusnya para lembaga amil zakat tu saling terintegrasi satu dengan lainnya. Dengan teknologi juga, dapat disusun database muzaki dan mustahik. Dengan sistem informasi ini, tidak akan terjadi pada muzaki yang sama didekati oleh beberapa lembaga amil, atau mustahik yang sama diberi bantuan oleh beberapa lembaga amil zakat.

Namun, bukan berarti dengan adanya sistem informasi zakat ini, tidak ada lagi rahasia dan strategi khas antarinstitusi. Sebab kehadiran sistem informasi zakat ini adalah hanya untuk mempermudah mengenali titik-titik lokasi yang telah digarap oleh suatu lembaga, dan titik lokasi mana yang belum menerima bantuan. Hal ini dapat mencegah terdapat lokasi pemberdayaan yang "gemuk" dan lokasi yang "kurus". Karena tujuan utama kehadiran lembaga amil zakat selain untuk mengelola dana zakat, juga untuk mengkoordinasikan agar zakat tersebut manfaat dan pengaruhnya dapat terasa bagi peningkatan kemakmuran dan kesejahteraan masyarakat. Akan tetapi sistem informasi ini haruslah dikelola oleh suatu institusi independen yang idealnya dikelola oleh negara.

Keenam, sikap mental para penerima Zakat. Kelemahan utama orang miskin sebagai penerima zakat sesunguhnya tidak hanya semata-mata kurang modal dalam menjalankan usaha, tetapi lebih pada sikap mental dan kesiapan manajemen usaha selain rendahnya etos kerja. Sikap inilah yang perlu mendapatkan perhatian serius dari para amil juga pemerintah.

\section{Strategi Pengembangan Organisasi Pengelola Zakat}

Seperti halnya sebuah perusahaan, organisasi pengelola zakat pun mesti memiliki strategi dalam merebut perhatian dari pasar donatur. OPZ telah harus memiliki pasar tersendiri yaitu, para wajib zakat, dan mempertahankan loyalitas mereka. Lebih dari itu OPZ juga bertanggung jawab untuk menumbuhkan kesadaran para wajib zakat agar membayarkan zakat mereka. Hal ini dipandang sangat penting untuk kontinuitas dan upaya pemberdayaan masyarakat yang mereka lakukan. Untuk itu, OPZ harus menciptakan strategi untuk melaksanakan tugas-tugas tersebut dengan baik. Strategi tersebut antara lain ${ }^{19}$, pertama, membudayakan kebiasaan membayar zakat. Penanaman kesadaran akan kewajiban zakat dilakukan sedini mungkin baik oleh lembaga formal maupun lembaga nonformal. Lembaga formal misalnya melalui madrasah-madrasah. Selain itu santri ataupun siswa diajarkan bagaimana membayar zakat. Selain itu LAZ ataupun BAZ dapat membuat brosur-brosur yang disebarkan kepada masyarakat, ataupun pengumumanpengumuman tentang kewajiban zakat. Pembiasaan sedini mungkin tentang zakat bagi generasi muda akan memiliki makna yang signifikan karena akan menjadi budaya ketika mereka sudah bekerja dan mendapatkan penghasilan. Pesan para kiai dan tokoh masyarakat ketika mereka berceramah dalam pelbagai kesempatan. Penghimpunan yang cerdas.

Para amil memiliki skill yang modern dalam mengumpulkan aset harta zakat dari para muzaki. Dengan datang menjemput bola, para amil dapat membantu penghitungan jumlah kekayaan para muzaki. Dengan itu akan dapat ditentukan jumlah kadar harta dan

\footnotetext{
${ }^{19}$ https://nurriantoalarif.wordpress.com
} 
berapa persen zakat dari harta tersebut setelah dikurangi kebutuhan primer dalam satu tahun.

Kedua, perluasan bentuk penyaluran. Pemberian zakat tidak harus selalu dalam bentuk konsumtif karena zakat konsumtif hanya akan memenuhi kebutuhan sesaat. Oleh karena itu, amil harus cerdas dan kreatif dalam mengelola aset harta zakat dan diserahkan dalam bentuk yang bervariasi. Sebelum zakat produktif itu diberikan akan lebih bermanfaat jika para mustahik diberikan pelatihan keterampilan yang sesuai dengan minat dan bakat. Dengan demikian, pengelola zakat tidak memberikan ikan saja, akan tetapi mampu memberikan kail untuk mecari ikan tersebut.

Kedua, sumber daya manusia yang berkualitas. Peningkatan kualitas sumber daya manusia merupakan suatu keharusan bagi OPZ jika lembaganya ingin terus berkembang sesuai dengan tujuan zakat itu sendiri. Untuk itu, perlu diberikan penghargaan yang pantas oleh OPZ kepada para pengelolanya. Hal ini dalam rangka memberikan semangat juga motivasi bagi para amil. Mereka memiliki dua motivasi dalam mengelola zakat. Di satu sisi mereka mencari meteri untuk memenuhi kebutuhan hidupnya di sisi lain, beribadah sambil mengamalkan ilmunya. Oleh karena itu, manajemen zakat di OPZ sudah saat tidak berdasarkan manajemen "lillâhi ta âla", melainkan manajemen yang profesional, akuntabel, amanah, dan memiliki integritas yang tinggi sehingga zakat semakin berdaya guna bagi masyarakat.

Ketiga, fokus dalam Program. OPZ tidak harus mendayagunakan zakat dengan pelbagai fokus dalam kehidupan yang mustahik. Lembaga inni saling bekerja sama dengan bidang yang berbeda-beda, sehingga pendayagunaan zakat bisa lebih terfokus. Dengan demikian, pendayagunaan zakat terlihat hasilnya dan memiliki peran yang besar dalam meningkatkan perekonomian umat. Satu lembaga fokus pada pelatihan keterampilan dan pemberian modal. Lembaga yang lain fokus pada bantuan bencana dan lain-lain.

Keempat, cetak biru pengembangan zakat. Setiap elemen dan institusi yang terkait dengan pengembangan dan pengelolaan zakat di Indonesia haruslah bersamasama dengan pemerintah merumuskan suatu arahan dan target-target jangka pendek, menengah, dan jangkan panjang dalam pengelolaan zakat. Jika institusi lain memiliki cetak biru pengembangan zakat, OPZ juga harus memiliki cetak biru pengembangan zakat. Untuk mewujudkan itu, idealnya pemerintah membentuk lembaga atau kementerian tersendiri yang mengurusi pengembangan dana zakat.

\section{Penutup}

Zakat merupakan kewajiban yang tidak dapat dihindari bagi setiap Muslim yang memenuhi rukun dan syarat-syarat tertentu. Pembayaran zakat ini dilakukan dalam rangka membersihkan jiwa maupun harta dari hal-hal yang tidak diridai Allah. Selain itu, zakat merupakan bentuk kepedulian Islam terhadap nasib fakir miskin. Dengan zakat, diharapkan dapat mengubah sesejahteraan mereka. Oleh karena itu, pemberian zakat tidak hanya berupa hal-hal yang bersifat konsumtif tetapi dapat berupa hal-hal yang produktif, seperti pemberian modal juga pelatihan keterampilan. Untuk mewujudkan itu, selain membutuhkan peran LAZ/BAZ/OPZ yang memiliki sumber daya manusia yang berkualitas juga dibutuhkan peran pemerintah secara maksimal. Sebagai negara yang mayoritas Islam, sudah dipandang perlu adanya lembaga atau kementerian yang khusus menangani zakat umat Islam Indonesia. []

\section{PustakaAcuan}

Ash Shiddiqy, Hasbi, Pedoman Zakat, Jakarta: Bulan Bintang 1984.

Aziz Dahlan, Abdul, dkk., Zakat Ensiklopedi Hukum Islam, Jakarta, PT Ichtiar Baru Van Hoeve, 1996.

Irkhami, Nafis. Islamic Work Ethics Membangun Etos Kerja Islami. Salatiga: STAIN Salatiga Press, 2014.

Hafidhuddin Didin, Zakat dalam Perekonomian Modern, Jakarta: Gema Insani, 2002.

Khallaf, Abdul Wahab, Sejarah Pembentukan dan Perkembangan Hukum Islam, disadur oleh Wajidi Sayadi, Jakarta, Raja Grafindo Persada, 2001.

Mahfud, Sahal, Nuansa Figh Sosial, Yogyakarta: LkiS, 2004.

Mufraini, M. Arif, Akuntasi dan Manajemen Zakat, Jakarta, Media Group, 2006.

Rofiq, Amad, Fiqh Kontekstual dari Normatif ke Pembaharuan Sosial, 2004, Yogyakarta, Pustaka Pelajar.

Suyitno (ed), Anatomi Fiqh Zakat, 2005, Yogyakarta: Pustaka Pelajar. 
104 Ahkam: Vol. XVI, No. 1, Januari 2016

Zuhayî, al-, Wahbah, Zakat Kajian Pelbagai Madzhab, diterjemahkan oleh Agus Efendi, Bandung, Remaja Rosda Karya, 1995. https://nrriantoalarif.wordpress.com

http://alarifs.blogspot.co.id

https://shareeducation.wordpress.com 